\title{
Effects of Climate on Forage Yields and Tree-ring Widths in British Columbia
}

\section{A. McLEAN AND J. H. G. SMITH}

HIghlight: On forested lands (1954 to 1969) 109 annual forage yields from 12 locations were studied. Very dry springs and unusually low annual precipitation resulted in low forage yields. Dry summer months were associated with superior yields provided the past year had been wet. The relationship was not consistent, however, nor was there a consistent relationship between tree-diameter growth and climate based on monthly or seasonal temperature or precipitation records. Annual forage yields were least on the Dewdrop and highest on the East Mara ranges, 325 and 1017 lb oven dry, respectively.

Forage yields on open rangelands (1954 to 1969), although only moderately associated with individual values for seasonal average temperature or total precipitation, could be estimated very well by all weather variables describing a 15-month period. The 190 observations of yield from 16 open rangeland locations averaged 544 $\mathrm{lb}$ oven dry, with a minimum of $84 \mathrm{lb}$ in 1967 and a maximum of $616 \mathrm{lb}$ in 1965 . Expressed as percentages of 1963 yields, annual forage weights averaged $116 \%$ and ranged from 53 to $214 \%$. Such large variations as a result of fluctuations in climate are of obvious importance to graziers, and the possibility that forage yields can be related to long-term variations in tree growth merits further study.

Weather, especially precipitation pattern, has a major influence on herbage production on rangelands. It would be useful in managing southern British Columbia rangelands to establish which type of weather data, over what period, has the greatest influence on forage yields. It should also be known whether or not data from existing nearby weather stations could be used to predict forage production.

The possibility of using trees to indicate long-term influences of climate and to estimate forage production for past years could be useful in reviews of rangemanagement programs. It, therefore, seemed worthwhile to determine whether or not tree growth was correlated with

The authors are ecologist, Canada Department of Agriculture, Research Station, Kamloops, B.C., and professor, Faculty of Forestry, University of British Columbia, Vancouver.

Manuscript received December 8, 1972. range herbage production.

Coupland (1958) reviewed a number of papers which demonstrated a relationship between climate and forage yield of grazing capacity on rangelands of Great Plains. Blaisdell (1958) indicated a good correlation between precipitation and herbage yields in southern Idaho. He concluded that precipitation prior to the start of the growing season influenced herbage yield more than precipitation during the growing season. Highest yields were apparently also associated with cool growing seasons. On the Front Range in Colorado, Currie and Peterson (1966) found that specific precipitation patterns accounted for $87 \%$ or more of the variation in forage yields of crested wheatgrass. Rainfall in April determined forage yield of spring-grazed ranges; May and July rainfall determined forage yields for fall-grazed ranges. Rogers and Peacock (1968) demonstrated the use of statistical decision theory as a technique whereby
Nevada ranchers may use observed information on precipitation to select the appropriate number of cattle to be wintered for turnout on the range the following year.

Much less has been done to correlate tree growth-rate with herbage production on forested rangelands. Basile (1971) concluded that site index for lodgepole pine was of no apparent value in predicting yields of herbaceous understory vegetation. Site index reflects the sum of growing conditions over several decades, however, rather than growing conditions for a single season.

Although our preliminary analyses of annual variations in forage yields and their averages by plant associations (McLean, 1969) were not associated with variations in widths of earlywood and latewood (Smith, 1970, Tables 10 to 12) we thought it worthwhile to do further studies. We were aware that growth of grasses, forbs, and shrubs will respond differently than trees do to variations in climate. Still, the possibility of using trees to indicate the very long-term influences of climate intrigued us. The impact of extremes of climate on forage yields can be of critical importance to graziers (Smith, 1969).

\section{Methods}

The methods used for collection of forage and determination of yields have been described by McLean (1969). Samples were harvested from permanent exclosures and areas free from tree competition. Methods for tree-ring analysis have been reviewed by several authors (Smith and Worrall, 1970). 
Table 1. Influence of locality on oven-dry yields (lb/acre) of forage and radial growth of nearby trees.

\begin{tabular}{|c|c|c|c|c|c|c|c|c|c|c|c|}
\hline \multirow[b]{3}{*}{ Location } & & & & \multicolumn{8}{|c|}{ Radial growth by species (percentage of 1963 growth) } \\
\hline & \multicolumn{3}{|c|}{ Yield of forage } & \multicolumn{4}{|c|}{ Douglas-fir } & \multicolumn{4}{|c|}{ Ponderosa pine } \\
\hline & lb/acre & $\begin{array}{l}\text { No. } \\
\text { years }\end{array}$ & $\begin{array}{l}\% \text { of } \\
1963\end{array}$ & $1^{1}$ & $\mathrm{e}$ & $1 \& \mathrm{e}$ & $\begin{array}{c}\text { No. } \\
\text { cores }\end{array}$ & 1 & $\mathrm{e}$ & $1 \& \mathrm{e}$ & $\begin{array}{c}\text { No. } \\
\text { cores }\end{array}$ \\
\hline Skookumchuck & 445 & 11 & 114 & - & - & - & - & 65 & 98 & 89 & 6 \\
\hline Kimberley & 719 & 10 & 90 & 58 & 81 & 73 & 6 & 77 & 79 & 78 & 6 \\
\hline Cranbrook & 587 & 9 & 132 & 63 & 74 & 67 & 5 & 83 & 100 & 96 & 7 \\
\hline Pechams Lake & 671 & 10 & 103 & 65 & 91 & 81 & 6 & 52 & 97 & 79 & 5 \\
\hline Newgate & 556 & 10 & 132 & 134 & 155 & 147 & 6 & 104 & 114 & 111 & 7 \\
\hline Rock Creek & 360 & 7 & 101 & 105 & 111 & 111 & 3 & 104 & 131 & 128 & 5 \\
\hline Goose Lake & 724 & 10 & 97 & 103 & 115 & 111 & 5 & - & - & - & - \\
\hline Lundbum & 886 & 10 & 104 & 97 & 96 & 96 & 6 & 127 & 114 & 116 & 5 \\
\hline Dewdrop & 325 & 9 & 152 & 142 & 123 & 128 & 6 & 116 & 138 & 132 & 5 \\
\hline West Mara & 343 & 8 & 72 & - & - & - & - & 62 & 89 & 80 & 6 \\
\hline East Mara & 1017 & 9 & 122 & 101 & 151 & 133 & 6 & 112 & 113 & 113 & 4 \\
\hline Rose Hill & 522 & 8 & 96 & 69 & 100 & 90 & 6 & 100 & 104 & 103 & 6 \\
\hline
\end{tabular}

${ }^{1} 1$, latewood; e, earlywood. Usually, two cores were available per tree.

In the fall of 1970 increment cores were collected from 28 Douglas-fir trees and 37 ponderosa pine trees. Two cores per tree were extracted either at 18 inches or $4.5 \mathrm{ft}$ above the ground. Widths of earlywood and latewood were measured by a Swedish Tree Ring Measuring Instrument. Then summaries were made for each of the locations (Table 1) and for each of the years for which forage weights were available. There was a total of 109 forage-yield-years. Since there were variable numbers of samples per year and not all years were studied, 1963, the best represented year, was taken as the base for calculation of percentage deviations. Forage weights for all years studied were averaged to determine a value for each location. Then average forage weights at cach location for each year were expressed as percentages of 1963 oven-dry weights and the percentages averaged. The process was repeated by inspecting the widths of earlywood (e), latewood (1), and whole rings $(\mathrm{e}+1)$ to find values for each of the years represented in the forage samples from 1954 to 1969. As in the oven-dry weights, tree-ring widths were expressed as a percentage of 1963 and averaged to determine the percentages shown for each tree species (Table 1). Variations in percentage forage yield and ring width components were inspected in relation tc differences in local climate.

Since yields of open rangelands which suffer most climatic stress might be better correlated with climate we turned next to statistical analysis of such plots. We used all available data from 16 localities in the vicinity of Princeton, 3 near Hedley, 3 near Keremeos, 3 near Rock Creek, 4 near Summerland, and 8 near Kamloops, eliminating all locations used in Tables 1 and 2. Again 1963 was used as the base year and percentages of forage yields calculated as appropriate to the years 1954-1969 represented by local sampling. British Columbia Department of Agriculture annual summaries of climate for the weather stations closest to each locality were consulted to determine average temperatures and total precipitation for each season. Summer was considered to include June, July, and August; fall was September, October, and November; winter was December, January, and February; spring was March, April, and May. In addition to the four seasons, a 15month total was calculated using e.g. 1953 summer, fall, 1953-54 winter, 1954 spring, and 1954 summer to estimate the effects of temperature and precipitation on 1954 forage yields. A total of 190 forage-yield-years were available for statistical analysis (Table 3). The climates appropriate to the individual localities and years sampled were weighted to get averages for temperature and precipitation. Percentage variations in forage yields for 1963 were calculated.

\section{Results}

Forage yields (Table 1) were repre-

Table 2. Annual variation in forage yields (lb/acre) on grazed forest ranges (1955-69) for representative localities.

\begin{tabular}{|c|c|c|c|c|c|c|c|c|}
\hline Year & $\begin{array}{l}\text { Skookumchuck } \\
(2700)^{1}\end{array}$ & $\begin{array}{c}\text { Kimberley } \\
(3000)\end{array}$ & $\begin{array}{c}\text { Cranbrook } \\
\quad(3050)\end{array}$ & $\begin{array}{l}\text { Newgate } \\
(2500)\end{array}$ & $\begin{array}{c}\text { Goose Lake } \\
\quad(3800)\end{array}$ & $\begin{array}{c}\text { Lundbum } \\
(3400)\end{array}$ & $\begin{array}{l}\text { Dewdrop } \\
(2100)\end{array}$ & $\begin{array}{c}\text { East Mara } \\
(2800)\end{array}$ \\
\hline 1955 & - & - & - & - & 722 & 599 & 220 & 756 \\
\hline 1956 & - & - & - & - & 797 & 646 & 441 & 1079 \\
\hline 1957 & - & - & - & - & 792 & 872 & 490 & 988 \\
\hline 1958 & & & & & & & & \\
\hline 1959 & 706 & 806 & - & 1142 & 872 & - & 316 & 1150 \\
\hline 1960 & 484 & 1120 & 1368 & 882 & 890 & 988 & 380 & 1702 \\
\hline 1961 & 462 & 582 & - & 550 & 772 & 1156 & 360 & 924 \\
\hline 1962 & 424 & 412 & 516 & 594 & 648 & 1312 & - & - \\
\hline 1963 & 390 & 796 & 446 & 420 & 746 & 854 & 214 & 834 \\
\hline 1964 & 296 & 480 & 532 & 438 & - & 802 & 196 & 958 \\
\hline 1965 & 306 & 624 & 480 & 420 & 420 & 796 & 308 & 762 \\
\hline 1966 & 408 & 808 & 520 & 468 & 578 & 832 & - & - \\
\hline 1967 & 294 & 695 & 461 & 196 & - & - & - & - \\
\hline 1968 & 452 & 866 & 376 & 446 & - & - & - & - \\
\hline 1969 & 674 & - & 793 & - & - & - & - & - \\
\hline Avg & 445 & 719 & 587 & 556 & 724 & 886 & 325 & 1017 \\
\hline No. years & 11 & 10 & 9 & 10 & 10 & 10 & 9 & 9 \\
\hline
\end{tabular}

${ }^{1}$ Elevation in feet. 
Table 3. Averages, variation, and correlation in annual forage yields on open rangelands and climatic factors for all years studied (190 observations).

\begin{tabular}{lrrrrrrrr}
\hline \hline & \multicolumn{9}{c}{ Summary of basic data } & & \multicolumn{2}{c}{ Simple correl. coef. } \\
\cline { 2 - 5 } \multicolumn{1}{c}{ Item } & Mean & \multicolumn{1}{c}{ S.D. } & \multicolumn{1}{c}{ Min. } & Max. & Coef.Var. & Weights & Percentages \\
\hline Forage yields (lb/acre) & 544 & 104 & 84 & 616 & 19.06 & & 1.000 & .262 \\
Percent of 1963 yields & 116 & 26 & 53 & 214 & 22.34 & .262 & 1.000 \\
Spring temperature $\left({ }^{\circ} \mathrm{F}\right)$ & 46 & 2 & 43 & 50 & 3.34 & -.332 & -.080 \\
Spring ppt (inches) & 2 & 6 & 1.3 & 3 & 30.79 & .264 & .332 \\
Summer temperature & 65 & 1 & 63 & 70 & 2.30 & -.209 & .287 \\
Summer precipitation & 4 & 1 & 0.9 & 5 & 34.64 & .213 & -.099 \\
Fall temperature & 45 & 3 & 41 & 50 & 5.58 & -.404 & -.296 \\
Fall precipitation & 3 & 0.6 & 1.4 & 5 & 23.80 & -.219 & -.525 \\
Winter temperature & 3 & 2 & 20 & 31 & 9.27 & -.077 & -.369 \\
Winter precipitation & 4 & 0.8 & 1.9 & 5 & 20.14 & .454 & -.173 \\
Past 15 month ppt & 16 & 3 & 10 & 20 & 16.61 & .315 & -.368 \\
Past 15 month avg temp & 48 & 2 & 43 & 54 & 4.43 & -.457 & -.068 \\
Year & 12 & 3 & 4 & 19 & 24.32 & -.282 & -.743 \\
Ycar ${ }^{2}$ & 168 & 71 & 16 & 361 & 42.21 & -.385 & -.697 \\
\hline
\end{tabular}

Table 4. Annual averages of forage yields on open rangelands and climatic factors, weighted by areas sampled, 1955-1969, excluding data on selected years.

\begin{tabular}{|c|c|c|c|c|c|c|c|c|c|}
\hline Item & 1955 & 1957 & 1959 & 1961 & 1963 & 1964 & 1965 & 1967 & 1969 \\
\hline Forage yield (lb/acre) & 424 & 524 & 525 & 611 & 574 & 569 & 616 & 84 & 257 \\
\hline Percent of 1963 yields & 133 & 148 & 120 & 133 & 100 & 101 & 111 & 53 & 154 \\
\hline Spring temperature $\left({ }^{\circ} \mathrm{F}\right)$ & 43 & 50 & 49 & 46 & 47 & 45 & 44 & 47 & 49 \\
\hline Spring ppt (inches) & 13 & 13 & 17 & 31 & 17 & 13 & 26 & 15 & 28 \\
\hline Summer temperature & 66 & 64 & 66 & 66 & 63 & 63 & 65 & 70 & 67 \\
\hline Summer precipitation & 3 & 5 & 3 & 3 & 5 & 5 & 3 & 1 & 5 \\
\hline Fall temperature & 43 & 47 & 44 & 41 & 48 & 43 & 45 & 50 & 47 \\
\hline Fall precipitation & 2 & 1 & 5 & 2 & 3 & 3 & 2 & 3 & 3 \\
\hline Winter temperature & 23 & 20 & 27 & 27 & 26 & 23 & 26 & 31 & 20 \\
\hline Winter precipitation & 4 & 3 & 3 & 5 & 4 & 5 & 5 & 4 & 4 \\
\hline Past 15 month ppt & 15 & 15 & 13 & 12 & 17 & 20 & 18 & 13 & 16 \\
\hline Past 15 month avg & 48 & 49 & 43 & 50 & 46 & 50 & 48 & 54 & 50 \\
\hline No. of plots & 5 & 5 & 3 & 32 & 37 & 25 & 32 & 3 & 3 \\
\hline
\end{tabular}

sentative of what might be expected in association with growth of trees near transitions from open range to scattered stands of commercial tree species. It is obvious, however, from the range in yields and the variety of tree species present, that local site conditions must be highly variable.

For the forested rangeland sites (Tables 1 and 2), it was not possible to find any consistent relationships between the variations in forage yield or tree growth and the records of monthly temperature or precipitation from the weather stations closest to each locality sampled. None of the yields (Table 2) were consistently related to variations in climate. Yields increased with elevation and were highly variable from year to year and among sites. Inspection of the weather records in relation to the tabulated yields suggested, however, that excessively dry springs and unusually low annual precipitation resulted in low yields. Dry summer months (June, July, and August) were associated with superior yields provided the past year had been wet.

For the 16 open rangeland sitcs, mul- estimate of $5.87 \%$. The best single variable was the average temperature for the past 15 months for estimation of weights of forage yields, which decreased from $1612 \mathrm{lb}$ per acre at the rate of 22.03 times the average temperature. This equation had a standard error of estimate of $92.5 \mathrm{lb}$ and a coefficient of determination of .208. Percentage forage yields decreased from $172.9 \%$ at the rate of 22.52 times average total fall precipitation. The standard error of estimate for the equation was high, $22.1 \%$, and the coefficient of determination was only .275 .

\section{Discussion}

The annual data (Table 4) illustrate the decrease in yields for late 1960's that lead to the significant negative effect of coded calendar date "year" or "year"". When studying Table 4 one must keep in mind the fact that our analysis, being weighted by the number of plots studied for each year, used the annual data according to the number of plots sampled. Also, one should note that although the past 15 months' temperature was the best single variable for estimation of forage weights, average winter precipitation was only slightly poorer. It also is remarkable that, although none of the variables is particularly efficient by itself, the combination of all 12 accounts for a very large proportion of the variation in forage yields.

The complexity of association of climate with forage yields makes it very difficult to inspect tabular data and recognize direct relationships. Similarly, the factors that govern distribution of growth within trees are complex and often not well interrelated. Some recent unpublished studies of lodgepole pine twigs, needles, and widths of earlywood have shown that wood growth and branch growth within the same tree in the same season are governed by different factors. Widths of earlywood at breast height for the years 1970,1969, and 1968 for 36 trees had simplc correlation coefficients as follows: with current twig length $r=.152$, with current needle length $r=.187$, with current needle width $r=.191$, and with current needle thickness $r=.055$. Much larger simple correlation coefficients were observed for widths of earlywood and latewood, $r=.877$, and ring width, $r=.989$.

Since both forage and wood yields are strongly influenced by climate, the possibility of extending records of annual 
forage yields back in time by use of tree-ring analysis still remains worthy of study. Further investigations should be made at comprehensively analysed sites to determine local effects of soil and climate by direct measurement of their effects on both growth and yield of forage and wood. Tree ring interpretations may be facilitated by data on maximum ring densities obtainable by $\mathrm{X}$-ray analyses of increment cores (Parker and Henoch, 1971). In addition, X-ray profiles of patterns of annual growth of tree rings might be related more consistently to climate and forage yields than the widths of earlywood and latewood that were used in this study.

\section{Literature Cited}

Basile, J. V. 1971. Site index for lodgepole pine-a poor indicator of site productivity for herbaceous plants. U.S. Dep. Agr. Intermountain Forest and Range Exp. Sta. Res. Note INT-152.

Blaisdell, J. P. 1958. Seasonal development and yield of native plants on the upper Snake River plains and their relation to certain climatic factors. U. S. Dep. Agr. Tech. Bull. $1190.68 \mathrm{p}$.

Coupland, R. T. 1958. The effects of fluctuations in weather upon the grasslands of the Great Plains . Bot. Rev. 24:273-317.

Currie, P. O., and G. Peterson. 1966. Using growing-season precipitation to predict crested wheatgrass yields. J. Range Manage. 19:284-288.

McLean, A. 1969. Plant communities of the Similkameen Valley, British Columbia, and their relationships to soils. Ph.D. Thesis. Washington State Univ., Pullman, Wash. 133 p.
Parker, M. L., and W. E. S. Henoch. 1971. The use of Englemann spruce latewood density for dendrochronological purposes. Can. J. Forest Res. 1:90-8.

Rogers, L. F., and W. S. Peacock. 1968. Adjusting cattle numbers to fluctuating forage production with statistical decision theory. J. Range Manage. 21:255-258.

Smith, J. H. G. 1969. Range ecosystem analysis: Interrelationships among soil, plants, and animals. Univ. Brit. Columbia Fac. of Forest. Mimeo., 17 p., plus Tables and Appendices.

Smith, J. H. G. 1970. Review of tree-ring analyses in British Columbia and "Where do we go from here?" In Smith and Worrall: 109-25.

Smith, J. H. G., and J. Worrall. 1970. Tree-ring analysis with special reference to Northwest America. Univ. Brit. Columbia Fac. of Forest. Bull. 7. 125 p. 